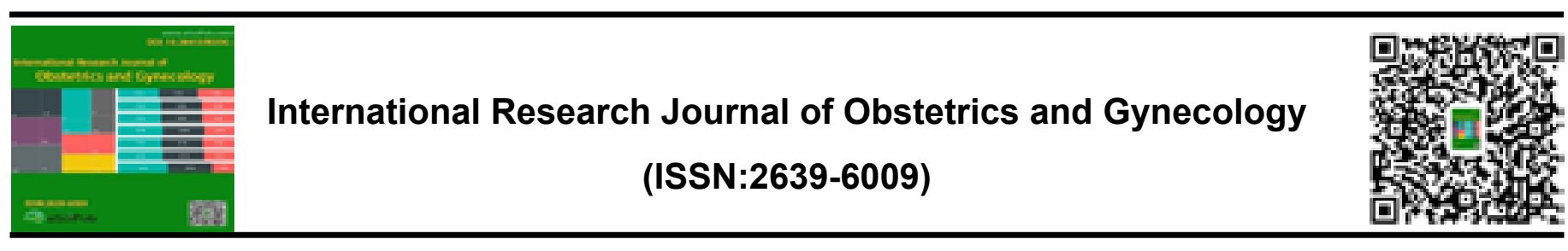

\title{
ANXIETY IN HIGH RISK MANAGERS IN ALAGOAS
}

Alice Correia Barros ${ }^{* 1}$ Leilane Camila Ferreira de Lima Francisco ${ }^{2}$ Jaqueline Michelle da Conceição $^{2}$ Alexandre $^{3}$ Mônica Santos Matos ${ }^{4}$ Verônica de Medeiros Alves ${ }^{5}$

${ }^{1,2}$ Enfermeira. Especialista em psiquiatria e saúde mental. Mestranda em enfermagem pela Universidade Federal de Alagoas. Membro do grupo de estudos em saúde mental, álcool e outras drogas da Universidade Federal de Alagoas. ${ }^{3}$ Acadêmica de enfermagem pela Universidade Federal de Alagoas. Membro do grupo de estudos em saúde mental, álcool e outras drogas da Universidade Federal de Alagoas. ${ }^{4}$ Enfermeira. Especialista em psiquiatria e saúde mental. Membro do grupo de estudos em saúde mental, álcool e outras drogas da Universidade Federal de Alagoas. ${ }^{5}$ Docente do curso de Enfermagem da Universidade Federal de Alagoas, Mestre em Ciências da Saúde, Doutora em Saúde Mental pelo Instituto de Psiquiatria da UFRJ

\section{ABSTRACT}

Introduction: Pregnancy needs to be evaluated with special attention because it lists physical, hormonal, psychic and social insertion changes that can reflect directly on your mental health. High-risk pregnant women may be afflicted with mental disorders such as anxiety and depression and this may have consequences for both maternal and fetal health. Objective: To evaluate the presence of anxiety signs and symptoms in high risk pregnant women in Alagoas. Methodology: Cross-sectional, descriptive study with quantitative approach. The research was conducted at the reference outpatient clinic for high risk pregnancy in the State of Alagoas: Professor Alberto Antunes University Hospital - HUPAA. For data collection we used the identification questionnaire containing social data for sample characterization and the anxiety inventory (STAl) that assesses signs and symptoms of anxiety as trait (STAI T) and state (STAI E) and classifies anxiety on high, moderate and low. The sample consisted of 100 pregnant women from a population of 400 high-risk pregnant women attended monthly and the survey was conducted between January and April 2019. Results: Regarding the presence of signs and symptoms of anxiety, we obtained STAI E classified as high (24 - 9.7\%), moderate (132 43.4\%) and low (91 - 36.8\%); and STAI T classified as high (19-7.6\%), moderate (147 - 59.5\%) and low (81 - 32.7\%). The study indicates that high-risk pregnant women may present signs and symptoms of anxiety, as it is a phase of life in which women experience feelings of fear and insecurity due to possible obstetric complications. Conclusion: High-risk pregnant women present situations that may interfere with the normal evolution of a pregnancy. Health professionals should be prepared to receive this risky pregnant woman and contribute to early identification and improvement of signs and symptoms of anxiety and depression of this pregnant woman. Final considerations: This study contributes to the early identification of signs and symptoms of anxiety in pregnant women during high risk prenatal care. It contributes to highlight the importance of qualified prenatal care that can minimize the risks that bring complications to the mental health of pregnant women through prevention strategies.

Keywords: Mental Disorder. Anxiety. High risk pregnancy.

*Correspondence to Author:

Alice Correia Barros

Enfermeira. Especialista em psiquiatria e saúde mental. Mestranda em enfermagem pela Universidade Federal de Alagoas. Membro do grupo de estudos em saúde mental, álcool e outras drogas da Universidade Federal de Alagoas.

How to cite this article:

Alice Correia Barros, Leilane Camila Ferreira de Lima Francisco,Jaqueline Michelle da Conceição Alexandre, Mônica Santos Matos, Verônica de Medeiros Alves.ANXIETY IN HIGH RISK MANAGERS IN ALAGOAS.International Research Journal of Obstetrics and Gynecology, 2020, 3:21

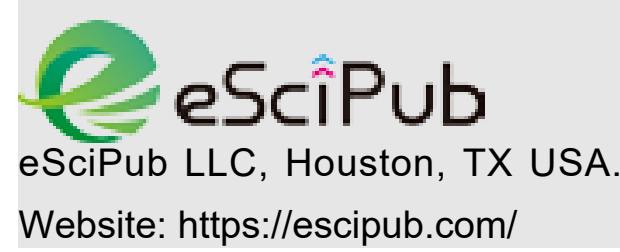

